\title{
READERS' FORUM
}

\section{英語教師の成長を促す自己評価 チェックリストの提案 Suggestions on Self-Evaluation Checklists for EFL Teachers in Japan}

三上明洋

\section{Akihiro Mikami}

\author{
近畿大学 \\ Kinki University
}

This paper aims to develop and suggest self-evaluation checklists for English as a Foreign Language (EFL) teachers in Japan as a reflection tool for their professional development. The paper first reviews existing theoretical studies on EFL instructors' professional competencies for creating a fundamental framework for the checklists. This framework consists of four parts: content knowledge and skills, pedagogical knowledge and skills, classroom teaching skills, and professional development knowledge and skills. Based on this framework, this paper develops self-evaluation checklists. It also discusses how they can be used to support EFL teachers' professional growth on the basis of the results of trial surveys with follow-up interviews. The checklists are expected to help the teachers periodically reflect on their overall professional competencies and thus stimulate their growth as EFL instructors. However, the efficacy of the checklists will need to be tested through nationwide surveys of EFL teachers in Japan.

本論では、現職英語教師が自分自身の成長を図るために使用できる自 己評価のための簡便なチェックリストを提案する。まず、先行研究に基づ き英語教師の専門能力を考察し、1. 教科の知識・技能、2. 教科を教える ための知識・技能、3. 教科指導技術、4. 教師の成長に関する知識・技能 からなる枠組みをまとめている。さらに、この枠組みに基づく自己評価チ エックリストを作成し、試験的にそれを活用した結果を基にその活用法を 考察している。本チェックリストの活用により、英語教師が自分の専門能 力を定期的・総合的により簡単に振り返ることができ、その向上にも役立 てることができるであろう。今後の課題としては、本チェックリストの有効 性を検証するための全国的な調査とその効果的な活用法に関する研究を 重ねる必要があるであろう。

\section{はじめに}

2012年8月、中央教育審議会による「教職生活の全体を 通じた教員の資質能力の総合的な向上方策について (答 申)」では、21世紀を生き抜くための力を育成する教員の 指導力が重要視され、日本の教員養成における改革の方 向性が示され、教職生活全体を通じた「学び続ける教員 像」の確立が提案されている。そこで本論では、日本の英 語教師が成長を目指して自らの専門能力を自己評価する ための簡便なチェックリストを作成し、その活用法を提案 したい。

\section{英語教師のための自己評価チェックリストの必 要性}

Wallace (1998)は、教師が成長を図るためには、専門的 実践に対する振り返りを繰り返すことが重要であると述べ ている。ところが、酒井他(2011)が指摘する通り、日本に おける公立学校の英語教師には欧米にあるような専門能 力基準は設定されておらず、何を目指して自分を成長さ せ、どのようにその成長を評価すればよいのかに関する 有益な情報はほとんど与えられていない。そのため、日本 の英語教師は多忙な日々に追われる中、どのように自分 の指導実践を振り返ればよいかさえも明らかにできない でいるのが現状であろう。

一方、EUにおいては、言語教師の成長を促進するた めにEuropean Portfolio for Student Teachers of Languages (EPOSTL)という言語教師教育用内省ツールが開発され ている(Newby他 2007; 石田他 2011)。これは、言語教師 を目指す学生が言語教育に求められる知識や技能を振り 返るための項目を示したものであり、自己評価の核となる 7領域193項目から成るcan-do descriptorsが含まれている。 近年、日本でもこのEPOSTLを修正し「言語教育履修生の ためのポートフォリオ(J-POSTL)」と「現職英語教員のため のポートフォリオ(J-POTL)」の開発が進められていることは 望ましいことである(JACET教育問題研究会 2013)。ただ し、EPOSTLには前述の通り200近い項目が含まれ、英語 教師が定期的に自分の実践を振り返るツールとしては活 用しにくいという問題点がある。J-POSTL/J-POTLにおいて は、半数ほどに項目数が削減されてはいるが、やはり100 項目のリス卜を使つて短時間で繰り返し実践を振り返るの は難しい。Wallace (1998)が指摘する通り、英語教師の専 門的成長には日常的・定期的な実践の振り返りが必要で あるとすれば、それを可能とする簡便なチェックリストの 開発が不可欠であろう。また、そのようなチェックリストが あれば、振り返りの内容や結果を他の教師などと共有しや すく、互いの成長を目指した協働関係の構築にも役立つに 違いない。

\section{英語教師の専門能力に関する枠組み}

前述のJ-POSTL/J-POTLは、日本の英語教師のための 内省ツールとして注目を集めていることは確かであるが、 ごちらも英語教師に必要な専門能力の考察からではな く、EPOSTLのcan-doリストをいかに日本に応用するかの 検討からその開発が始められている点で注意が必要であ る。英語教師の専門能力に含まれる領域は非常に広く明 確にその定義を示すことは容易ではないが、まずは英語 教師が備えるべき核となる専門能力とはどのようなもの 
なのかを検討する必要があろう。その上で、それらをチエ ツクリストとして提示することができれば、英語教師自ら がより具体的に専門能力を振り返るためのツールとして 活用できるに違いない。

それでは、英語教師の専門能力とはどのようなもので あろうか。まず、Freeman (1989)によれば、言語教育を教 師の意思決定プロセスであると捉えた場合、その意思決 定を構成する要素として、1. knowledge(教科の内容に加 えて、教育が実践される社会文化的環境や生徒に関する 知識)、2. skills (教材提示など教師が実践できなければ ならない技術）、3. attitude（教師が、自分自身、教育活動、 学習者との間で採用する態度)、4. awareness(ある事柄に 注意を向けたり、向けている注意をモ二ターしたりする能 力であり、前述の3つの要素を統合するもの)の4つに分類 できると提案されている。これは、英語教師に求められる 専門性の全体像を把握するのに役立つが、各要素に含ま れる下位能力を明確にしたい場合にはどうしても具体性 に欠けてしまう。

また、文部科学省(2003)によれば、英語教師がコミュ二 ケーション能力を育成するために必要とされる指導力と は、実際に英語授業を計画・実践・評価・改善する力から なる「英語授業力」であり、それは1。「教職」として求めら れる資質能力、 2 . 英語運用能力、 3 . 英語教授力という3 の側面を持った統合的能力であると述べられている。

さらに、近年では授業実践能力に加え英語教師の成長 という観点もその専門能力の要素として新たに取り入れ られている。特にRoberts (1998)と八田(2000)の2つの研究 は、英語教師の成長を考慮しその専門能力の全体像を提 示するだけでなく、具体的な下位能力に関するリス卜も含 んでいるため、本論ではこれらの2つの研究を基に英語教 師の専門能力に関する枠組みを考察してみたい。

まず、Roberts (1998)は、言語教師に必要な知識・技術 を、1.contentknowledge (対象言語に関する知識や能力)、 2. pedagogic content knowledge(対象言語を教えるための 知識)、3. general pedagogic knowledge(授業運営に関す る知識や技術）、4. curricular knowledge(教材や試験に 関する知識など)、5. contextual knowledge(学習者や学 校などの特徵に関する知識など)、6. process knowledge
(教師の成長を可能にする技術や態度)に分類している。 さらに、これを基に八田(2000)は、日本の教育環境を考慮 し、外国語としての英語教育環境や学習指導要領に関す る知識などを含めた上で、1. 教科の知識、2. 教科を教え るための知識、3. 外国語としての英語教育についての基 礎的な知識、4. 英語教育のコンテクストの理解、5. 教科 指導・指導技術という分類を提案している。したがって、 日本の英語教師の専門能力の枠組みとしては、この八田 (2000)の分類が参考になるが、改良の必要な点もある。 まず、前述の2 と3 に関する知識の境界が曖昧である。ま た、4 については、日本の教育環境や学習者の動機づけ などに関する理解が含まれるが、これらは5 に含まれる教 室での授業実践のための前提となる知識であるとも考え られ、これらの明確な区別も難しい。そこで、八田(2000) が提案する5分野のうち、2と3の知識を統合し「教科を教 えるための知識・技能」とし、同じく4と5を統合し「教科指 導技術」とすることにより、重複を少なくできると考えられ る。さらに、八田(2000)では、Roberts (1998)によるProcess knowledgeと呼ばれる教師の成長につながる技術や態度 があまり重要視されていない点も注意が必要であり、新た に「教師の成長に関する知識・技能」を追加する方が望ま しいであろう。

したがって本論では、日本における英語教師の専門能 力とは、1. 教科の知識・技能 (英語に関する知識・技能)、

2. 教科を教えるための知識・技能 (教職全般や英語教育 に関する専門的知識・技能）、3. 教科指導技術 (教室にお ける指導技術)、4. 教師の成長に関する知識・技能 (教師 としての成長を図るために必要な知識・技能) という4分野 から構成される総合的な能力と捉えることとする。なお、 図1はこれらをまとめて表したものである。

\section{英語教師のための自己評価チェックリストとそ の活用法}

前述の英語教師の専門能力に関する枠組みに基づき 自己評価チェックリストを作成し、その具体的な項目を示 したものが表1である。ここに含まれるチエック項目は、八 田(2000)とRoberts (1998)に加えて、EPOSTL (Newby他

\section{図 1 : 英語教師の専門能力に関する本論で扱う枠組み}

\begin{tabular}{|c|c|c|}
\hline Roberts (1998) & 八田(2000) & 英語教師の専門能力 ( 4 分野) \\
\hline content knowledge & 教科の知識 & 教科の知識·技能 \\
\hline pedagogic content knowledge & 教科を教えるための知識 & \multirow[b]{2}{*}{ 教科を教えるための知識・技能 } \\
\hline curricular knowledge & $\begin{array}{c}\text { 外国語としての英語教育につい } \\
\text { ての基礎的な知識 }\end{array}$ & \\
\hline contextual knowledge & 英語教育のコンテクストの理解 & \multirow[b]{3}{*}{ 教師の成長に関する知識·技能 } \\
\hline general pedagogic knowledge & \multirow{2}{*}{ 教科指導·指導技術 } & \\
\hline process knowledge & & \\
\hline
\end{tabular}


2007)、J-POSTL/J-POTL (JACET教育問題研究会 2013)、 Mikami (2011)、西野(2011)を参考に作成された。本于エ ックリストの活用法はとても簡単であり、英語教師自身で 4分野32項目のすべてについて振り返りを行い、それぞれ 6段階 $(1=$ 全然あるいはほとんどあてはまらないから6= 常に、あるいはかなりあてはまる)で自己評価を記入する だけである。

本チェックリストの有用性を確認するため、2名の公立 中学校英語教師 (教師 $\mathrm{A}$ : 教職経験 2 年目、男性; 教師 $\mathrm{B}$ : 教 職経験 1 年目、女性) から協力を得て、本チェックリス卜に よる振り返りを約7か月間の間隔を置いて合計2回試行し た (実施時期:第1回、2014年6月;第2回、翌年1月)。また、 第2回目の試行後には、各教師の振り返りの内容と結果あ るいは本チェックリストの有用性について、筆者が各教師 に対して約10分間インタビュー調査を実施した。なお、2 名の教師の勤務校は異なり、すべて別々に実施された。

その結果、このインタビュ一調査を通じて本チェックリス 卜活用の利点 (3点) と問題点 (1点)が確認された。

利点1 分野別能力の確認：本チェックリス卜の活用に より、どちらの教師も個々の能力を具体的に 振り返り、どの能力が高いあるいは低いかを 把握できた。例えば、教師Bは、授業を実践す る能力に比べ、英語 4 技能の能力不足を痛感 し、TOEICスコアを高めたいという能力向上の ための目標も設定できた。

利点2 能力の変化の確認： 実施時期の異なる2回分 の自己評価結果を比較することにより、どちら の教師も自らの能力の変化を確認できた。例え ば、教師Bは英語の文法構造・語法に関する能 力向上を発見できた。その理由として、英語が 苦手な生徒にわかりやすく説明をするために日 々勉強をしているからと振り返つていた。

利点3 振り返りの促進： 各教師と筆者が振り返りの内 容と結果を話し合う際に、本チェックリストを使 用しない場合に比べそれを使用した場合には、 各教師による振り返りを深めることができた。初 めに本チェックリストなしで専門能力について 話し合いをしたところ、教師Aはただ漠然とすべ てにおいて自信がないと述べるにとどまったが、 本チェックリストを参照しながら話し合いをする と、ペアワークやグループワークの活動はうまく できていると気づかせることができた。

問題点1 活用の難しさ：教師Aからは、チェックリス卜を 渡されただけではその活用の仕方がわかりにく いという意見が寄せられた。したがって、単なる 自己評価の実施だけでは十分に活用されない かもしれない。

このように、上記試行結果によれば、本チェックリスト は英語教師がより具体的に自らの専門能力を振り返るた めの効果的なツールとなることが期待できる。ただし、そ の活用においては、教師を指導する立場の者(例えば指 導主事、先輩・同僚教師など) が英語教師と連携して評価 結果を共有し、専門能力の向上に向けた他者からのフィー ドバックを得られるようにすることが望ましいであろう。

\section{終わりに}

本論では、英語教師の専門能力に関する枠組みに基 づき、英語教師が定期的・継続的に専門能力を自己評価
するための簡便なチェックリス卜を作成し、その活用法を 提案した。今後は、英語教師を対象とする全国規模の調 査を通して本チェックリス卜の有効性を検証し、自己評価 の結果を効果的に成長につなげる方法についてもさらに 研究を重ねていきたい。

\section{表 1 : 英語教師のための自己評価チェツクリスト}

\section{I . 教科の知識・技能 (8項目)}

1. 英語教師として十分な英語の語彙力があると思う

2. 英語教師として十分な英語の聞く力があると思う

3. 英語教師として十分な英語の話す力があると思う

4. 英語教師として十分な英語の読む力があると思う

5. 英語教師として十分な英語の書く力があると思う

6. 英語教師として英語の文法構造・語法などを十分に理解 している

7. 英語教師として英語圈の文化について十分に理解している

8. 生徒に対して英語学習の意味や利点を説明できる

II . 教科を教えるための知識・技能 (8項目)

9. 生徒の意欲を高める学習目標を設定できる

10. 生徒の興味に合わせた適切な教材を選択できる

11. 生徒の英語力に合わせた適切な教材を選択できる

12. 生徒のつまずきそうなところが予測できる

13. 生徒の理解度を見ながら、いろいろな質問や例文を臨機 応変に準備できる

14. 生徒の日本語の知識に配慮し、英語を指導する際にそれ を活用できる

15. 日本語と英語の言語習得の違いなどについて十分な知識 があると思う

16. 主な教授法・教授理論に関する十分な知識があると思う

III. 教科指導技術 (8項目)

17. 学習指導要領に基づいて、授業を計画・実践できる

18. 生徒の二ーズに基づいて、授業を計画・実践できる

19. クラスの実態を踏まえて、授業を計画・実践できる

20. 英語学習に効果的なクラスの雾囲気を作り出すことがで きる

21. 英語を使つて授業を展開できる

22. 生徒が授業活動において英語を使うように促すことがで きる。

23. 生徒の英語運用能力を適切な方法で評価できる

24. クラス全体の授業、小グループによる授業、ペアによる授 業などを使い分けることができる

$\mathrm{IV}$. 教師の成長に関する知識・技能 (8項目)

25. 自分の授業について、客観的に反省(リフレクション)を行 うことができる

26. 計画・実行・反省の手順で、生徒や授業に関する課題に気 づくことができる。

27. 生徒からのフィードバックや学習の成果に基づいて、自分 の授業を批判的に評価できる。

28. 同僚や指導教諭等からのフィードバックを受け入れ、自分 の授業に取り入れることができる。

29. 関連する理論や研究成果を取り入れて授業を改善できる

30. 生徒の学習の伸びを適切な方法で評価できる。

31. 他の教員と授業を計画することができる

32. 同僚の授業を観察し、建設的にフィードバックできる 


\section{謝辞}

本研究は、日本学術振興会科研費基盤研究 (C) (課題 番号26370753)の助成を得ている。また、数々の貴重なご 指摘やご助言を査読委員の先生方よりいただいた。心よ り感謝申し上げる。

\section{引用文献}

中央教育審議会.(2012).「教職生活の全体を通じた教員の資質 能力の総合的な向上方策について (答申) 」. http://www. mext.go.jp/b_menu/shingi/chukyo/chukyo0/toushin/1325092.htm（2014年6月14日検索）.

Freeman, D. (1989). Teacher training, development and decision-making. TESOL Quarterly, 23, 27-45.

八田立二. (2000).『反省的授業実践 リフレクティブ・アプローチ による英語教師の養成』東京:金星堂.

石田雅近・神保尚武・久村研・酒井志延 (編)。(2011) 『英語教師 の成長一求められる専門性』東京:大修館書店.

JACET教育問題研究会. (2013).『英語教師の成長に関わる枠組 みの総合的研究』(平成24年度科学研究費補助金基盤研究 (B)研究成果報告書)

Mikami, A. (2011). Changes experienced by teachers through action research projects in an in-service EFL teacher education program. JACET Journal, 53, 57-74.

文部科学省. (2003).『「英語が使える日本人」の育成のための英語 教員研修ガイドブック』東京:開隆堂出版.

Newby, D., Allan, R., Fenner, A., Jones, B., Komorowska, H., \& Soghikyan, K. (2007). European portfolio for student teachers of languages: A reflection tool for language teacher education. Graz: ECML, Council of Europe.
西野孝子. (2011).「コミュニカティブ・アプローチに関する日本人 高校英語教師の信条と実践」JALT Journal, 33, 131-156.

Roberts, J. (1998). Language Teacher Education. London: Arnold.

酒井志延・神保尚武・高梨庸雄・久村研.(2011).「英語教師の成 長」. 石田雅近・神保尚武・久村研・酒井志延(編)、『英語教師の 成長一求められる専門性』(pp.189-227). 東京: 大修館書店.

Wallace. M. J. (1998). Action research for language teachers. Cambridge: Cambridge University Press.

\section{著者略歴}

三上 明洋(Akihiro Mikami)は、

千葉大学大学院修士課程修了後、

私立高校教諭、高等専門学校講師 を経て、現在近畿大学経営学部准 教授。専門は、英語教育学であり、 特に教師教育、アクション・リサー チ、授業改善などに関心がある。 著書は、『ワークシートを活用した 実践アクション・リサーチ一理想的 な英語授業をめざして』(大修館書 店 2010）。主な論文に、Changes experienced by teachers through action research projects in an in-service EFL teacher education program (JACET Journal, 53, 2011) などがある。

\section{[RESOURCES] MY SHARE}
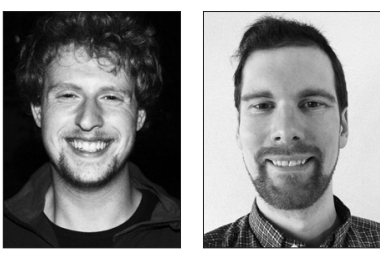

Greetings, and welcome to another edition of My Share. We hope that during the long summer vacation readers have had the opportunity to take a break from the hustle and bustle of the average workday and ponder possible ways to innovate lessons and challenge students. We certainly have had those questions on our mind, and if you have too, why not make like the authors below and share your ideas by submitting to My Share?

We start this issue with a submission by Charles McLarty, who introduces some intrigue into the classroom with a whodunnit mystery sure to capture the imagination of any student. Next up, Rachel Manley draws from real life and authentic entertainment materials to teach the absolutely essential skill of making requests. Then, James Jensen suggests a way to ease student concerns over pronunciation and simplify the regular past tense. Finally, we end with Annie Menard, who proves once more that Bingo is an inexhaustible source of educational fun. Enjoy!

\section{The Whodunnit Mystery: A Game that Gets Students Listening Actively, Thinking Creatively, and Communicating}

\section{Charles McLarty}

Hokkaido University of Information Science <charles@do-johodai.ac.jp> 


\section{Quick guide}

» Keywords: Mystery, communication, cooperation

"Learner English level: Elementary to advanced

Learner maturity: High school and above

Preparation time: 10-15 minutes

Activity time: 25-45 minutes, depending on class size and level

» Materials: Blackboard and chalk

This game, recommended by a former colleague, has gotten consistently favorable responses from students. It provides practice using simple questions while getting students to listen carefully and communicate better with classmates.

\section{Preparation}

Step 1: Tell students that a crime has happened on campus and that they must solve it. After students calm down, explain that this "crime" is a story you have created and that they must solve the mystery by asking you questions to determine what has happened.

Step 2: Explain that students must find answers to the four items written on the blackboard. They are: (1) the criminal, (2) the victim, (3) the weapon, and (4) the place. For advanced classes, you can add a fifth item, the motive, but this is not necessary.

Step 3: Check student comprehension by providing definitions in their first language for criminal, victim, weapon, and place. Tell students that both the criminal and victim are in the classroom! When I first play this game in class, I usually play the criminal to see how soon students realize my chicanery. After all, the teacher is also in the classroom!

Step 4: Tell students they must ask questions about the four written items in order, finding the answer to item 1 before asking about item 2 and the answer to item 3 before asking about item 4 . Only questions giving yes or no answers are allowed.

Step 5: Give additional hints as necessary. Write suggestions on the board for ways students can ask about items. For example, for item 1 ask "Is the criminal wearing glasses, blue jeans, sports shoes?" or for item 2 ask "Does the victim have black/ brown/blond hair?" and so on.

\section{Procedure}

Step 1: Write the four answers down on paper to avoid any temptation to change them during the game. Next, assign groups. I usually put students into groups of two or three. When students find all four answers, the game is over. Offer rewards or bonus points to groups who announce answers correctly during the game if feasible.

Step 2: Decide the order in which groups ask questions. In round one, each group decides (either by janken or coin toss) which member will ask the group's question. After one round, go back to the first group. The member who did not ask a question in round one must do so now. For three-student groups, the two who have not asked a question can decide who will ask next.

Step 3: Choose some common object as the weapon (I usually choose an object in the classroom). Sometimes, I choose things that could not be real weapons, like my sunglasses.

Step 4: By now, many classes will have found answers to items 1 and 2 . When students have found answers $1-3$, tell them to guess number 4 by gut instinct. I usually make number 4 a place everyone knows, such as the school library. If class time is waning, let groups guess number 4 by raising hands. When a group gets answer 4 , give them a reward or prize.

\section{Conclusion}

This is a good game to play after lessons on describing people. This game requires students to pay attention to other groups' questions as well as teacher responses in order to gain hints about what to ask on their next turn. I have witnessed an increase in students talking to members of other groups, people they had seldom tried to communicate with previously. Also, students are motivated to communicate with their own group to help each other get bonus points or rewards. The atmosphere of tension and excitement slowly builds as students both compete with and cooperate with their classmates to get the answers. For these reasons, I highly recommend teachers try this game.

\section{A Pragmatic Activity Rachel A. Manley}

Kanda University of International Studies <ramanley1@gmail.com>

\section{Quick Guide}

" Keywords: Pragmatics, requests, speech acts, media, movies, TV Shows

» Learner English Level: Intermediate

» Learner Maturity: High school to adult

» Preparation Time: 15 minutes 
Materials: Copies of appendix worksheets.

Speech acts are an important concept for students to learn, because it is essential for them to understand and create language appropriate to different situations they might encounter. This paper deals with the speech act of requests. However, any speech act is teachable using the activities provided. Students might not know which requests are appropriate for certain situations in the target language. Finding authentic language in an EFL setting is difficult. One way students can learn speech acts in an EFL setting is through media such as movies and TV shows.

\section{Preparation}

Print out appendices A, D, E, and F for each student and print one copy of appendices B and C for every two students. You can modify the documents to suit your needs.

\section{Procedure}

Step 1: Start the class with the warm-up question: "What is a request?" Students brainstorm what factors influence requests, why they occur, and why they are needed.

Step 2: Pass out the dialogue worksheet (Appendix A) and two pair work activities (Appendices B \& C). Students practice making requests orally to better understand requests. During the activity they will have a conversation with each other in order to practice speaking. You can have the students share their dialogue created with Appendix C.

Step 3: Students get into groups of two or three and create a dialogue using one of the topics listed on their worksheet (see Appendix D). The scenarios are different from one another and feature request topics students might encounter. The topics are also vast and realistic, which helps with authenticity. Once students finish creating dialogues (usually ten lines per person) you can have them share their dialogue with the class.

Step 4: Pass out the data collection worksheet (Appendix E). After you explain the different parts of the worksheet to the students, they will complete it with a recent request event that has happened to them, whether they did the requesting or someone requested something from them. This activity can also be done as homework. Teachers can adjust the worksheets according to the criteria they would like students to focus on.
Step 5: Next class or if time permits: Students are given another data collection worksheet. Play a movie or TV show and have students find the pragmatics (i.e. requests) in the media. Using media provides examples of authentic conversations as well as violations of acceptable behavior, which is important especially if students are in an EFL setting. A short but effective sitcom would be The Big Bang Theory. It is good to show students when violations occur and the reaction others have toward them. Also, students can be asked how they would rectify their mistake if they were to make this violation.

\section{Variation}

For Step 5, you can also use a modified data collection worksheet (Appendix F). This can be used for a movie where one or more speech acts are used (or more than one request is made) for students to practice more.

\section{Conclusion}

Learning pragmatics is essential for students, especially when they study abroad or come in contact with people from other countries. In order to avoid miscommunication, misunderstandings, and other problems, knowing the correct form of pragmatics is necessary. Students learn what their topic is (pragmatics), practice it, apply it to real-life, and then observe a situation where it occurs (using media).

\section{Appendices}

The appendices are available from the online version of this article at <http://jalt-publications.org/ tlt/departments/myshare $>$.

\section{The Regular Past: Teaching Only Two Pronunciations}

\author{
James C. Jensen \\ Aka-Kara English \\ <jensen@leto.eonet.ne.jp>
}

\section{Quick guide}

"Key Words: Regular past tense

» Learner English Level: Low

» Learner Maturity: Junior high and above

»Preparation Time: 5 minutes 
Say liked with the past tense phoneme $d$ instead of the proper $t$. The regular past tense $t / d$ distinction is inconsequential; it makes no difference in comprehensibility. I would venture that it is minor compared to other pronunciation problems your students have, so I suggest reducing the regular past tense to two pronunciations. Tell your students to consider $t$ and $d$ interchangeable as long as they do not add an extra syllable, the $I d$, which should only be used for verbs that end in t or d. And importantly, students must not add $o$ or $u$ to the end of the word as is common with Japanese speakers.

\section{Procedure}

Step 1: Start with an explanation in simple English of the regular past tense. Teach or review the difference between voiced and unvoiced consonants. This should be easy because Japanese signals voicing in its writing (e.g., とど). Tell the students the verb suffix -ed is pronounced $t$ with verbs that end in voiceless sounds and as $d$ in verbs ending in voiced sounds (including vowels).

Step 2: Explain there is a natural reason for this and draw a chart of the consonants English has in common with Japanese on the board: $P / B, T / D, S / Z$, $K / G$. To show why the past tense has three pronunciations, and to explain that it is natural, demonstrate how the pronunciation works. That is, say a word such as tap, circle the $P$, and draw a line to the voiceless $T$. Say "tapped." Repeat this with several examples and then do the same with words that end in voiced consonants. Circle $G$, a voiced consonant, and say "jogged" drawing a line to the voiced $D$.

Step 3: Tell the students the $t / d$ distinction is important, but that they need not worry about pronouncing it. As their English improves it will become natural. In the meantime, it does not matter! Stress how the distinction between $t$ and $d$ is an inconsequential mistake as long as they do not add an extra syllable, saying "tap-ped", or even worse, "tap-ped-do" for example.

Step 4: Returning to the chart of consonants, show that the only verbs that add an extra syllable are those that end in $t$ or $d$. Explain how a vowel is inserted between the last consonant and the final $d$, and, point out how $I d$ is added to make a syllable. Land, for example, becomes lan-ded, and the two-syllable word vi-sit, becomes three syllables vi-si-ted.

Step 5: To check whether the students understand and can hear the difference between the voiced, unvoiced, and Id pronunciations, write some verbs on the board (Examples are given in the appendix). Write $t, d$, and $I d$ on the board. Pronounce the words and have students put them into the correct column. Then have students pronounce them to each other and stress that $t$ and $d$ are interchangeable as long as the speaker does not add an unnecessary syllable before the suffix or an $o$ or $u$ after it.

\section{Conclusion}

The greatest benefit of presenting the regular past tense in this way is the relief it affords beginner level students. If you tell your students not to worry about the $t$ and $d$, that it makes little difference, and that the distinction will come naturally as their English improves, it will go a long way in easing their anxiety.

The biggest concern a teacher might have is that mispronounced words may become fossilized. This should not be a concern. There is a phonetic reason for the different pronunciations and as the students improve those natural factors will come into play.

\section{Appendix}

The appendix is available from the online version of this article at <http://jalt-publications.org/tlt/ departments/myshare $>$.

\section{Educational Bingo}

\section{Annie Menard \\ Tokai University Foreign Language Center <shamuskii@gmail.com>}

\section{Quick Guide}

" Key Words: Methodology, speaking, vocabulary

» Learner English Level: Beginner and above

» Learner maturity level: Any

» Preparation time: About an hour

»Activity time: From 10 minutes to the whole class period

» Materials: The handouts you created

Every student, no matter how old, enjoys playing bingo. I have used bingo in my classes for years, but always with an educational twist to it. This version includes group work, a worksheet, a vocabulary list, and finally, the bingo sheet itself. 


\section{Preparation}

Step1: Decide on the theme of your bingo game: Summer, sports, adjectives, Halloween, etc.

Step 2: Make a vocabulary handout with 25 pictures on it. Each picture has an empty line under it for the students to write the word for the picture. On the back of the handout, in alphabetical order, write all the answers that go with the pictures. This ensures that every student has the same answer for each picture. It also provides them with the correct spelling and cuts down on time taken to use a dictionary.

Step 3: Using the same pictures, create bingo sheets for your students. One bingo sheet per student; all bingo sheets should be different.

\section{Procedure}

Step 1: In class, put the students into groups of three or four, depending on your class size. This way, they can help each other match the pictures and vocabulary.

Step 2: Distribute the vocabulary handouts. Tell the students they have all the answers on the back, and all they have to do is to write the correct word under the correct picture.

Step 3: While the students are matching words and pictures on their handouts, take one extra bingo sheet, cut out all the pictures individually, and place all of them in a small bag. During the game you will draw the pictures from the bag to choose the next word to call out.

Step 4: Go over the answers as a class to ensure every student has the correct word matched to the correct picture.

Step 5: Distribute one bingo sheets to each student.

Step 6: Give the students the bingo rules. Rule 1: They must memorize the words and not write them down on their bingo sheet. Rule 2: When students achieve a bingo they come to the teacher and say the words that form the bingo. Rule 3: They can get multiple bingos. The game does not end after the first student gets a bingo. It continues until there is no more time left or until there are only four pictures left in the bag.

Step 7: After you have verified a student's bingo, cross it out on their bingo sheet using a highlighter, as they will be back with other bingos later on.

\section{Variations}

Any vocabulary topic can be used for this game depending on your needs. You can either give the students color or black and white copies of the handouts and bingo sheets. You can easily skip the preparation step 3 and have the students make their own bingo sheets, but it takes more class time and more supplies such as scissors and glue. Also, there is no need to use 25 pictures. The game can easily be reduced to 16 or 9 vocabulary items. Finally, you can provide the vocabulary again on the back of the bingo sheets for extra help.

\section{Conclusion}

This is one of my most successful games. I also noticed that the more useful the vocabulary, the easier it is for the students and the more effort the students put into it. By grouping the students, they help each other with the answers, looking for the pictures during the bingo game, and memorizing the vocabulary for their trip to the teacher's desk. I also noticed that they repeat the words after I call them, again, in preparation for their trip to the teacher's desk. Bingo can be so much more than just a time killer. Be creative!

español - 조선어 - 한국어- 汉语 - le français - Deutsch -pý́cский
язык - Bahasa Indonesia - Tiếng Việt - Português ภาษา เทย

Do not miss this!

Other Language Educators

invite you to the

\section{4th Annual JALT OLE SIG Conference LanguageS PLUS}

Language learning and teaching beyond the first foreign language

(母国語である) 日本語、あるいは第一外国語 としての英語以外の外国語教育

Oct. 24 and 25, 2015

2015年10月24日(土)\&25日(日)

Venue: Chukyo University, Nagoya, Aichi

http://www.chukyo-u.ac.jp/index.html

主催: 中京大学

干466-8666 愛知県名古屋市昭和区八事本町 101-2

Conference information: http://www.geocities.jp/dlinklist/ ENG/2015OLE-Conference.html

Please inform teachers of languages other than English and Japanese of this opportunity. We look forward to meeting you, so you can

- tell us about the FL teaching situation at your school

- network with colleagues, students, and others

英語及び日本語以外の教授に関わつている同僚の方にもご案内くだ さい。この学会では次の点も歓迎します：

・ あなたの学校及び大学での外国語教授の状況についての情報

・同僚、教員、学習者、その他とのネットワーキング、意見および 情報交換など 